\title{
A desinfecção como barreira sanitária na prevenção de Doenças Transmitidas por Alimentos (DTA): sensibilidade de amostras de Staphylococcus aureus isoladas em alimentos no IPB-LACEN/RS, nos anos de 2002 a 2006, frente ao hipoclorito de sódio*
}

\author{
JANE MARI CORRÊA BOTH
}

César Augusto Marchionatti Avancini (Orientador - UFRGS)

As doenças transmitidas por alimentos provocam perdas humanas, sociais e econômicas, sendo que, para a prevenção de suas ocorrências, a higienização (limpeza e desinfecção) do ambiente de processamento e manipulação é procedimento de relevante importância. Para promover a segurança microbiológica dos alimentos, os compostos inorgânicos liberadores de cloro livre estão entre os desinfetantes químicos mais utilizados. No entanto, as evidências indicam que não há agente químico antimicrobiano frente aos quais os microrganismos não apresentem ou não possam ser selecionados por algum grau de resistência. Para obter dados sobre a ação do cloro como barreira sanitária, o objetivo deste trabalho foi o de verificar, frente ao hipoclorito de sódio, a sensibilidade de 32 amostras de Staphylococcus aureus isoladas no IPB/LACEN/RS de alimentos envolvidos em surtos de DTA entre os anos 2002 e 2006. Através do teste de suspensão, simularam-se condições de uso: concentração de 200 ppm de cloro livre, na ausência e na presença de matéria orgânica (1\% de leite U.H.T. integral); subconcentração de 100 ppm de cloro livre; e quatro tempos de contato (5, 10, 15 e 30 minutos). A 200 ppm, na ausência de matéria orgânica, as 32 amostras foram sensíveis, sendo que, aos 10 minutos, 31 delas já estavam inativadas. A 200 ppm, na presença de matéria orgânica, mesmo aos 30 minutos de contato, 27 foram resistentes. Com 100 ppm de cloro livre, foram necessários 30 minutos de contato para que 24 amostras apresentassem sensibilidade. Concluiu-se que a sensibilidade das amostras foi influenciada pela concentração, pela presença de matéria orgânica e pelo tempo de contato. Considerando as condições do experimento quanto à efetividade do cloro como barreira sanitária em DTA, frente ao Staphylococcus aureus, esses três fatores precisam ser levados em consideração.

Descritores: Staphylococcus aureus, hipoclorito de sódio, desinfecção, antimicrobianos: resistência, doenças transmitidas por alimentos. 


\title{
The disinfection as sanitary barrier in the prevention of foorborne diseases: sensitivity of isolated samples of Staphylococcus aureus in foods in the IPB-LACEN/ RS, in the years of 2002 to 2006, front to the sodium hypochlorite.**
}

\author{
JANE MARI CORRÊA BOTH
}

\author{
César Augusto Marchionatti Avancini (Adviser - UFRGS)
}

Committee: Claudiomar Soares Brod (UFPEL), Eduardo César Tondo (UFRGS), José Maria Wiest (UFRGS)

Foodborne diseases cause human, social and economic losses. Their ocurrence can be avoided chiefly by cleaning and disinfection measures in processing and manipulation premises. Inorganic chlorine compounds are among the most common chemical disinfectants used to promote microbiological food safety. However, evidences indicate that microorganisms are capable to present or develop some degree of resistance to practically every known chemical agent. So, in order to obtain data regarding chlorine compounds as a sanitary barrier, this work evaluated the sensitivity, to sodium hypochlorite, of 32 samples of Staphylococcus aureus isolated at IPB-LACEN/RS from food involved in foodborne diseases outbreaks occurred between 2002-2006. Through the suspension test, usage conditions were simulated: a 200 ppm free chlorine solution in the absence and presence of organic matter (1\% UHT whole milk); a sub-concentration of $100 \mathrm{ppm}$ free chlorine solution; and four contact times (5, 10, 15 and 30 minutes). At the concentration of $200 \mathrm{ppm}$, in absence of organic matter, all the 32 samples were sensitive. After 10 minutes, 31 of them were already inactivated. At 200 ppm, in presence of organic matter, 27 strains were resistant even after a contact of 30 minutes. At $100 \mathrm{ppm}$ free chlorine concentration, simulating a sub concentration usage, it was necessary a 30 minutes contact to 24 samples demonstrate some sensitivity. It was concluded that the sensitivity of samples was influenced by concentration, presence of organic matter and contact time. In view of the experimental conditions relative to chlorine efficacy as a sanitary barrier, in foodborne diseases associated to Staphylococcus aureus, these three factors must be considered.

Key words: Staphylococcus aureus, sodium hypochlorite, disinfection, antimicrobial: resistance, foodborne diseases.

\footnotetext{
***Master's Thesis \# 446 (Field: Epidemiology, Sanitation and Prophylaxis). 53p. Graduate Program in Veterinary Sciences [www.ufrgs.br/ ppgcv], Faculdade de Veterinária, Universidade Federal do Rio Grande do Sul (UFRGS), Porto Alegre, RS/Brazil. CORRESPONDENCE: J.M.C. Both [janeboth@gmail.com].
} 